\title{
One-pot synthesis of tetracyclic fused imidazo[1,2-a]pyridines via a three-component reaction
}

\author{
Bo Yang, Chuanye Tao, Taofeng Shao, Jianxian Gong ${ }^{*}$ and Chao Che*
}

\author{
Letter \\ Address: \\ Laboratory of Chemical Genomics, Engineering Laboratory for Chiral \\ Drug Synthesis, School of Chemical Biology and Biotechnology, \\ Peking University Shenzhen Graduate School, Shenzhen 518055, \\ China

\section{Email:} \\ Jianxian Gong* - gongjx@pku.edu.cn; Chao Che ${ }^{*}$ - \\ chec@pkusz.edu.cn \\ * Corresponding author \\ Keywords: \\ Groebke-Blackburn-Bienaymé reaction; imidazo[1,2-a]pyridines; \\ multi-component reaction; one-pot reaction
}

\author{
Beilstein J. Org. Chem. 2016, 12, 1487-1492. \\ doi:10.3762/bjoc. 12.145 \\ Received: 07 May 2016 \\ Accepted: 29 June 2016 \\ Published: 18 July 2016 \\ Associate Editor: D. Spring \\ (C) 2016 Yang et al.; licensee Beilstein-Institut. \\ License and terms: see end of document.
}

\begin{abstract}
A novel three-component reaction has been developed to assemble biologically and pharmaceutically important tetracyclic fused imidazo[1,2-a]pyridines in a one-pot fashion utilizing readily available 2-aminopyridines, isatins and isocyanides. The three-component coupling proceeds through the Groebke-Blackburn-Bienaymé reaction followed by a retro-aza-ene reaction and subsequent nucleophilic reaction of the in-situ generated imidazo[1,2-a]pyridines bearing an isocyanate functional group.
\end{abstract}

\section{Introduction}

Multicomponent reactions (MCRs) have attracted considerable attention in organic and medicinal chemistry due to their high efficiency, simple operability, atom economy and unmatched versatility [1-6]. Especially, these reactions serve as an ideal synthetic tool for the assembly of structurally diverse and biologically relevant heterocycles, and thus have been extensively investigated by organic and medicinal chemists to explore lead compounds in drug discovery efforts [7-10].

The imidazo[1,2-a]pyridine scaffold is a pharmaceutically important drug template, and its derivatives display a broad range of biological activities such as antibacterial [11-13], antiviral $[14,15]$, anti-inflammatory $[16,17]$, antitumor [18-20], and anti-
HIV [21]. It is found as the core structure in several drugs such as Zolpidem, Alpidem and Zolimidine (approved for treatments of insomnia, anxiety and peptic ulcers, respectively) [22]. As such, the imidazo[1,2-a]pyridine structure represents an intriguing synthetic target, and its further functionalization is leading to polycyclic fused heterocycles that may have interesting biological profiles [23].

Impressively, the imidazo[1,2- $a]$ pyridine scaffolds can be constructed in great diversity by a multicomponent reaction of amidines, aldehydes and isocyanides. This MCR, a variant of the Ugi reaction $[24,25]$, was discovered independently by three groups and is known as the Groebke-Blackburn-Bienaymé 
(GBB) reaction [26-29]. The reaction involves a formal [4+1] cycloaddition of isocyanides [30] and imines, generated from the amidines and aldehydes, allowing straightforward access to diverse imidazo[1,2-x]azines [31-33].

In view of the significance of the GBB reaction and the imidazo[1,2- $a]$ pyridine core structure, the further development of new GBB-based methods for the efficient synthesis of novel polycyclic fused imidazo[1,2-a]pyridines is highly desirable. In an earlier study, we have developed a GBB/lactamization MCR strategy, which provided the rapid access to isoquinolinonefused imidazo[1,2-a]pyridines with potent and selective CDK2 inhibition properties [34,35]. As a continuing effort, we report herein our recent efforts in the development of a GBB-based MCR method for the one-pot synthesis of diverse quinazolin-2one fused imidazo[1,2-a]pyridines (Scheme 1). Parts of the work have been disclosed in a previous patent [36].

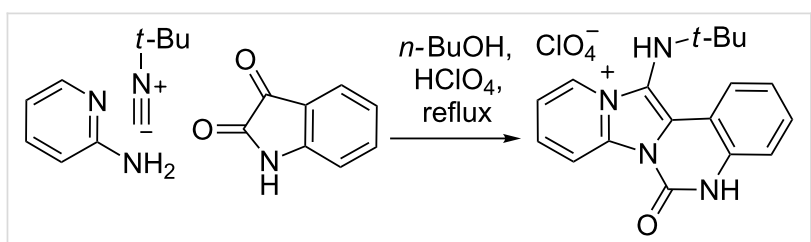

Scheme 1: MCR to polycyclic fused imidazo[1,2-a]pyridine derivatives.

\section{Results and Discussion}

It is noteworthy that there was no report on a ketone-involving GBB reaction, and several attempts to explore the GBB reaction utilizing ketones as carbonyl reactant failed [27,37]. These difficulties could be partially explained in terms of the electronic and steric effect of the ketone involved. More importantly, when a ketone is used in the reaction the formed unstable $[4+1]$ cycloaddition adduct could not undergo a [1,3]-alkyl shift. On the other hand the reaction with an aldehyde allows further conversion through a [1,3]-hydride shift to form a stable and aromatic imidazole. Therefore, we envisioned that a ketoneinvolved reaction could proceed, if the $[4+1]$ cycloaddition adduct can further rearrange to form an aromatic imidazole. With this idea in mind, we started to study an isatin-involved GBB reaction $[38,39]$, because the resulting $[4+1]$ cycloaddition adduct could further proceed with a retro-aza-ene reaction via a concerted [1,5]-hydride shift.

We first explored the reaction of 2-aminopyridine (2a), isatin (3a) and tert-butyl isocyanide (4a). Under the classical reaction conditions (entry 1, Table 1), the product 1 a was isolated only in $4 \%$ yield. Performing the reaction under reflux conditions slightly improved the yield to $11 \%$. We next examined solvent effects in this MCR reaction and various solvents were screened, as summarized in Table 1.
Table 1: Synthesis of imidazo[1,2-a]pyridine derivatives in indicated conditions [36]. ${ }^{\text {. }}$

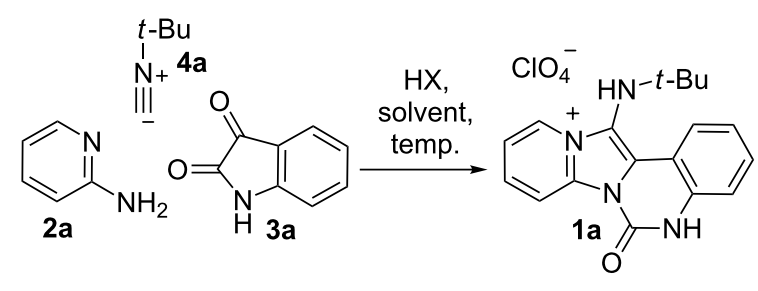

\begin{tabular}{|c|c|c|c|c|}
\hline Entry & Solvent & Acid & Temperature & Yield (\%) \\
\hline 1 & $\mathrm{MeOH}$ & $\mathrm{HClO}_{4}$ & $\mathrm{rt}$ & 4 \\
\hline 2 & $\mathrm{MeOH}$ & $\mathrm{HClO}_{4}$ & reflux & 11 \\
\hline 3 & $\mathrm{MeCN}$ & $\mathrm{HClO}_{4}$ & reflux & $--^{\mathrm{b}}$ \\
\hline 4 & DMF & $\mathrm{HClO}_{4}$ & $100^{\circ} \mathrm{C}$ & 10 \\
\hline 5 & $\mathrm{EtOH}$ & $\mathrm{HClO}_{4}$ & reflux & 17 \\
\hline 6 & iPrOH & $\mathrm{HClO}_{4}$ & reflux & 22 \\
\hline 7 & $n-\mathrm{BuOH}$ & $\mathrm{HClO}_{4}$ & reflux & 30 \\
\hline 8 & iBuOH & $\mathrm{HClO}_{4}$ & reflux & 21 \\
\hline 9 & $t-\mathrm{BuOH}$ & $\mathrm{HClO}_{4}$ & reflux & 19 \\
\hline 10 & $\begin{array}{l}\text { isopentyl } \\
\text { alcohol }\end{array}$ & $\mathrm{HClO}_{4}$ & reflux & 17 \\
\hline 11 & $\mathrm{CF}_{3} \mathrm{CH}_{2} \mathrm{OH}$ & $\mathrm{HClO}_{4}$ & reflux & 13 \\
\hline 12 & $n-\mathrm{BuOH}$ & PTSA & reflux & 20 \\
\hline 13 & $n-\mathrm{BuOH}$ & $\mathrm{HCl}$ & reflux & - \\
\hline 14 & $n-\mathrm{BuOH}$ & $\mathrm{AcOH}$ & reflux & - \\
\hline 15 & $n$-BuOH & $\mathrm{HClO}_{4}$ & reflux & $42^{\mathrm{c}}$ \\
\hline
\end{tabular}

aConditions: 2a (1 mmol), $\mathbf{3 a}(1 \mathrm{mmol}), \mathbf{4 a}(1 \mathrm{mmol})$, and acid $\mathbf{H X}$

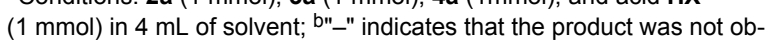
tained; conditions: $\mathbf{2 a}(1.35 \mathrm{mmol}), \mathbf{3 a}(1 \mathrm{mmol}), \mathbf{4 a}(1.35 \mathrm{mmol})$, and acid $\mathbf{H X}(1 \mathrm{mmol})$ in $4 \mathrm{~mL}$ of solvent.

We observed that protic solvents with medium polarity can facilitate the reaction by product precipitation from the reaction mixture and $n$ - $\mathrm{BuOH}$ proved to be the most suitable solvent in the reaction. Performing the reaction in refluxing $n-\mathrm{BuOH}$ in the presence of one equivalent of $\mathrm{HClO}_{4}$ for $8 \mathrm{~h}$, compound $\mathbf{1 a}$ was obtained in $30 \%$ isolated yield. Other acids including $p$-toluenesulfonic acid (PTSA), $\mathrm{HCl}$, and HOAc were also screened, and the results indicated that the use of PTSA led to a slightly decreased yield, and weaker acids failed to promote this process. It is worth noting that the reaction proceeded incompletely and significant amounts of isatin (3a) were recovered. When increased amounts (1.35 equiv) of 2-aminopyridine (2a) and tert-butyl isocyanide (4a) were used, the yield of $\mathbf{1 a}$ could be further improved to $42 \%$.

Under the optimized reaction conditions, we started to investigate the reaction scope. The MCR of various 2-aminopyridines, isatins and isocyanides proceeded well under the optimized conditions and the combinational synthesis delivered structurally diverse quinazolin-2-one-fused imidazo[1,2-a]pyridines (Figure 1). It was found that the electronic properties of the 


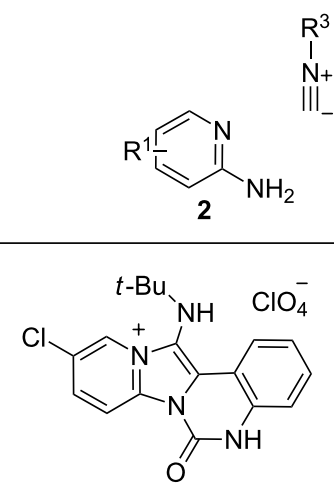

1b: $53 \%$ from $\mathbf{2 b}, \mathbf{3 a}$ and $\mathbf{4 a}$<smiles>COc1ccc2[nH]c(=O)n3c(c(NC(C)(C)C)[n+]4cc(Cl)ccc34)c2c1</smiles>

1f: $39 \%$ from $\mathbf{2 b}, \mathbf{3 b}$ and $\mathbf{4 a}$<smiles></smiles>

$\mathbf{1 j}$ : $39 \%$ from $\mathbf{2 a}, \mathbf{3 d}$ and $\mathbf{4 a}$<smiles></smiles>

1n: $52 \%$ from $2 c, 3 a$ and $4 b$<smiles>COc1ccc2[nH]c(=O)n3c(c(NC4CCCCC4Cl)[n+]4cc(Br)ccc34)c2c1</smiles>

1r: $38 \%$ from $\mathbf{2 d}, \mathbf{3 b}$ and $\mathbf{4 b}$<smiles>O=c1[nH]c2ccc(Br)cc2c2c(NC3CCCCC3)[n+]3cc(Br)ccc3n12</smiles>

1v: $37 \%$ from $\mathbf{2 d}, \mathbf{3 d}$ and $\mathbf{4 b}$
$\mathrm{R}^{3}$<smiles>[R][X]1=C=CC2=C(C=C1)C(=O)C(=O)N2</smiles>

1c: $38 \%$ from $\mathbf{2 c}, \mathbf{3 a}$ and $\mathbf{4 a}$<smiles>COc1ccc2[nH]c(=O)n3c(c(NCC(C)(C)C)[n+]4cc(Br)ccc34)c2c1</smiles>

1g: $48 \%$ from $2 \mathrm{~d}, \mathbf{3 b}$ and $\mathbf{4 a}$

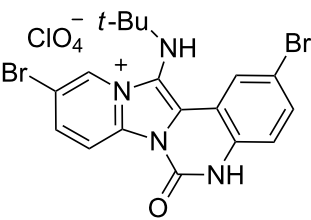

1k: $35 \%$ from $\mathbf{2 d}, \mathbf{3 d}$ and $\mathbf{4 a}$<smiles>O=c1[nH]c2ccccc2c2c(NC3CCCCC3)[n+]3cc(Cl)ccc3n12</smiles>

1o: $48 \%$ from $2 b, 3 a$ and $4 b$<smiles>O=c1[nH]c2ccc(Cl)cc2c2c(NC3CCCCC3)[n+]3cc(Cl)ccc3n12</smiles>

1s: $51 \%$ from $2 b, 3$ c and $4 b$

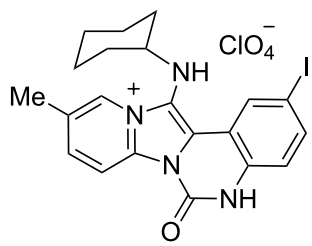

1w: $36 \%$ from $\mathbf{2 c}, \mathbf{3 g}$ and $\mathbf{4 b}$

$-\mathrm{BuOH}, \mathrm{HClO}_{4}$, reflux

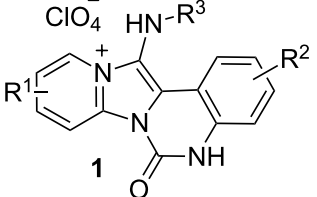<smiles>CC(C)(C)Nc1c2c3ccccc3[nH]c(=O)n2c2ccc(Br)c[n+]12</smiles>

1d: $55 \%$ from 2 d, $3 \mathbf{a}$ and $4 a$

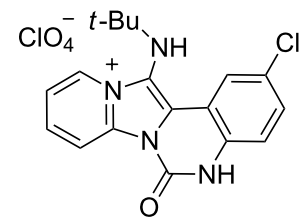

1h: $37 \%$ from $2 a, 3 c$ and $4 a$<smiles>Cc1cc(C)c2[nH]c(=O)n3c(c(NC(C)(C)C)[n+]4cc(Cl)ccc34)c2c1</smiles>

1I: $40 \%$ from $2 b, 3 e$ and $4 a$<smiles>O=c1[nH]c2ccccc2c2c(NC3CCCCC3)[n+]3cc(Br)ccc3n12</smiles>

1p: $45 \%$ from 2 d, $3 \mathbf{a}$ and $\mathbf{4 b}$<smiles>O=c1[nH]c2ccc(Cl)cc2c2c(NC3CCCCC3)[n+]3cc(Br)ccc3n12</smiles>

1t: $40 \%$ from 2 d, 3 c and $4 b$<smiles>O=c1[nH]c2c(F)cccc2c2c(NC3CCCCC3)[n+]3cc(Br)ccc3n12</smiles>

1x: $33 \%$ from $\mathbf{2 d}, \mathbf{3 f}$ and $\mathbf{4 b}$<smiles>COc1ccc2[nH]c(=O)n3c(c(NC(C)(C)C)[n+]4cc(C)ccc34)c2c1</smiles>

1e: $50 \%$ from 2 c, 3 b and $\mathbf{4 a}$<smiles>CC(C)(C)Nc1c2c3cc(Cl)ccc3[nH]c(=O)n2c2ccc(Br)c[n+]12</smiles>

1i: $41 \%$ from $2 d, 3 c$ and $4 a$<smiles>CC(C)(C)Nc1c2c3cccc(F)c3[nH]c(=O)n2c2ccc(Cl)c[n+]12</smiles>

1m: $38 \%$ from $\mathbf{2 b}, \mathbf{3 f}$ and $\mathbf{4 a}$<smiles>COc1ccc2[nH]c(=O)n3c(c(NC4CCCCC4Cl)[n+]4cc(Cl)ccc34)c2c1</smiles>

1q: $47 \%$ from $\mathbf{2 b}, \mathbf{3 b}$ and $\mathbf{4 b}$<smiles>O=c1[nH]c2ccc(Br)cc2c2c(NC3CCCCC3)[n+]3cc(Cl)ccc3n12</smiles>

1u: $34 \%$ from $\mathbf{2 b}, \mathbf{3 d}$ and $\mathbf{4 b}$<smiles>Cc1cc(C)c2[nH]c(=O)n3c(c(NC4CCCC4Cl)[n+]4cc(Cl)ccc34)c2c1</smiles>

1y: $38 \%$ from $2 \mathrm{~b}, 3 \mathrm{e}$ and $\mathbf{4 b}$

Figure 1: Syntheses of imidazo[1,2-a]pyridine derivatives. Reaction conditions: 2 (1.35 mmol), $3(1 \mathrm{mmol}), 4(1.35 \mathrm{mmol}), \mathrm{HClO} 4(1 \mathrm{mmol}), n$-BuOH $(4 \mathrm{~mL})$, reflux. Yields refer to isolated yields. $2 b R^{1}=4-\mathrm{Cl} ; 2 c R^{1}=4-\mathrm{Me}, 2 d R^{1}=4-B r ; 3 b R^{2}=5-O M e ; 3 c R^{2}=5-C l ; 3 d R^{2}=5-B r ; 3 e R^{2}=5,7-M e$; 3f $\mathrm{R}^{2}=7-\mathrm{F} ; \mathbf{3 g} \mathrm{R}^{2}=5-\mathrm{I} ; \mathbf{4 b} \mathrm{R}^{3}=$ cyclohexyl. 
substituents attached to the isatin and 2-aminopyridine had no obvious effect on the reactivity. When tert-butyl isocyanide (4a) was used, the reaction proceeded equally well with electron-withdrawing or electron-donating substituted isatins and 2-aminopyridines, delivering the desired products $\mathbf{1 b}-\mathbf{m}$ in $35-55 \%$ yield. Similar results were obtained from the reaction with cyclohexyl isocyanide (4b) to give $\mathbf{1 n}-\mathbf{y}$. All products were characterized by ${ }^{1} \mathrm{H}$ NMR, ${ }^{13} \mathrm{C}$ NMR, HRMS spectra and the structure of 10 was further confirmed by X-ray diffraction analysis (see Supporting Information File 1 for details).

A possible mechanism for the MCR is proposed in Figure 2. The MCR proceeds through the formation of a protonated imine species from 2-aminopyridine and isatin which then undergoes a formal $[4+1]$ cycloaddition with isocyanide to generate a spiro intermediate $\mathbf{b}$. The spiro compound then undergoes a retro-aza-ene reaction via a [1,5]-hydride shift resulting in an aromatic imidazo[1,2-a]pyridine having an isocyanate functional group. A further intramolecular nucleophilic reaction of the imidazole and the newly generated isocyanate provides the final product 1 . Noteworthy, the benzodiazepinone-fused imidazo[1,2-a]pyridine 5 was not observed which may be due to the strain of the seven-membered ring.

\section{Conclusion}

In conclusion we have developed a GBB-based multicomponent reaction of isatins, 2-animopyridines and isocyanides, which provides a direct and rapid access to diverse tetracylic fused imidazo[1,2-a]pyridines with moderate yields. To the best of our knowledge, the described chemistry represents the first example of the GBB reaction involving ketones, transforming the simple starting materials into complex heterocycles of pharmaceutical relevance in a highly efficient fashion. The developed MCR proceeds through a domino GBB/retro-aza-ene/ nucleophilic cyclization process under mild reaction conditions, and its high efficiency and simple operation will make it have potential applications in the compound library synthesis.

\section{Experimental}

Typical procedure for multicomponent reaction. To a solution of isatin (3,1.0 mmol), 2-aminopyridine (2, $1.35 \mathrm{mmol})$ and isocyanide $(4,1.35 \mathrm{mmol})$ in $4 \mathrm{~mL}$ of $n$-butyl alcohol was added $\mathrm{HClO}_{4}(1.0 \mathrm{mmol})$, and the reaction mixture was stirred under refluxing temperature for $8 \mathrm{~h}$. When the reaction mixture had cooled to room temperature, the formed precipitate was collected by filtration, rinsed with ethanol and dried to afford the target compounds $\mathbf{1}$.

\section{Supporting Information}

\section{Supporting Information File 1}

Experimental procedures, characterization and spectral data for synthesized compounds and X-ray data for compound 10.

[http://www.beilstein-journals.org/bjoc/content/ supplementary/1860-5397-12-145-S1.pdf]

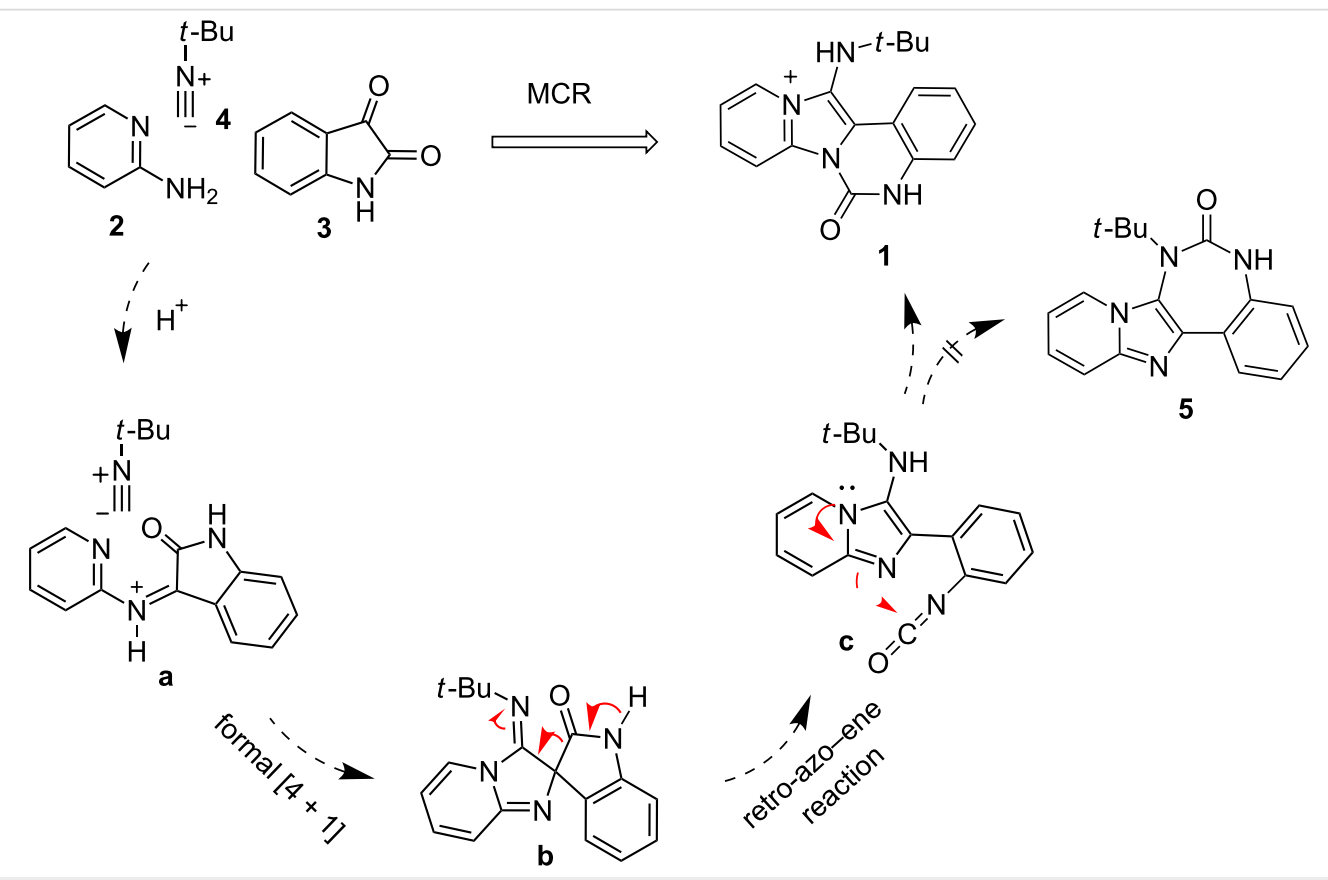

Figure 2: Mechanistic rationale for the MCR [36]. 


\section{Acknowledgements}

This work has been supported by the National Natural Science Foundation of China (Grant No. 21102006), Natural Science Foundation of Guangdong Province (Grant No. S2011010000185), and Shenzhen Basic Research Project (No. JCYJ20140417144423193).

\section{References}

1. Dömling, A.; Ugi, I. Angew. Chem., Int. Ed. 2000, 39, 3168-3210. doi:10.1002/1521-3773(20000915)39:18<3168::AID-ANIE3168>3.0.CO ;2-U

2. Zhu, J. Eur. J. Org. Chem. 2003, 1133-1144. doi:10.1002/ejoc.200390167

3. Dömling, A. Chem. Rev. 2006, 106, 17-89. doi:10.1021/cr0505728

4. Koopmanschap, G.; Ruijter, E.; Orru, R. V. A. Beilstein J. Org. Chem. 2014, 10, 544-598. doi:10.3762/bjoc. 10.50

5. Trost, B. M. Science 1991, 254, 1471-1477. doi:10.1126/science.1962206

6. Bienaymé, H.; Hulme, C.; Oddon, G.; Schmitt, P. Chem. - Eur. J. 2000, 6, 3321-3329. doi:10.1002/1521-3765(20000915)6:18<3321::AID-CHEM3321>3.0.C O;2-A

7. Dömling, A.; Wang, W.; Wang, K. Chem. Rev. 2012, 112, 3083-3135. doi:10.1021/cr100233r

8. Akritopoulou-Zanze, I. Curr. Opin. Chem. Biol. 2008, 12, 324-331. doi:10.1016/j.cbpa.2008.02.004

9. Weber, L. Curr. Med. Chem. 2002, 9, 2085-2093. doi:10.2174/0929867023368719

10. Hulme, C.; Ayaz, M.; Martinez-Ariza, G.; Medda, F.; Shaw, A. Recent Advances in Multicomponent Reaction Chemistry: Applications in Small Molecule Drug Discovery. In Small Molecule Medicinal Chemistry: Strategies and Technologies; Czechtizky, W.; Hamley, P., Eds.; Wiley: Weinheim, Germany, 2015; pp 145-187. doi:10.1002/9781118771723.ch6

11. Abrahams, K. A.; Cox, J. A. G.; Spivey, V. L.; Loman, N. J.; Pallen, M. J.; Constantinidou, C.; Fernández, R.; Alemparte, C.; Remuiñán, M. J.; Barros, D.; Ballell, L.; Besra, G. S. PLoS One 2012, 7, e52951. doi:10.1371/journal.pone.0052951

12. Shukla, N. M.; Salunke, D. B.; Yoo, E.; Mutz, C. A.; Balakrishna, R.; David, S. A. Bioorg. Med. Chem. 2012, 20, 5850-5863. doi:10.1016/j.bmc.2012.07.052

13. Al-Tel, T. H.; Al-Qawasmeh, R. A. Eur. J. Med. Chem. 2010, 45 , 5848-5855. doi:10.1016/j.ejmech.2010.09.049

14. Hamdouchi, C.; de Blas, J.; del Prado, M.; Gruber, J.; Heinz, B. A.; Vance, L. J. Med. Chem. 1999, 42, 50-59. doi:10.1021/jm9810405

15. Lhassani, M.; Chavignon, O.; Chezal, J.-M.; Teulade, J.-C.; Chapat, J.-P.; Snoeck, R.; Andrei, G.; Balzarini, J.; De Clercq, E.; Gueiffier, A. Eur. J. Med. Chem. 1999, 34, 271-274. doi:10.1016/S0223-5234(99)80061-0

16. Lacerda, R. B.; de Lima, C. K. F.; da Silva, L. L.; Romeiro, N. C.; Miranda, A. L. P.; Barreiro, E. J.; Fraga, C. A. M. Bioorg. Med. Chem. 2009, 17, 74-84. doi:10.1016/j.bmc.2008.11.018

17. Rupert, K. C.; Henry, J. R.; Dodd, J. H.; Wadsworth, S. A.; Cavender, D. E.; Olini, G. C.; Fahmy, B.; Siekierka, J. J. Bioorg. Med. Chem. Lett. 2003, 13, 347-350. doi:10.1016/S0960-894X(02)01020-X

18. Lima, C. F.; Costa, M.; Proença, M. F.; Pereira-Wilson, C. Eur. J. Pharm. Sci. 2015, 72, 34-45. doi:10.1016/j.ejps.2015.02.019
19. Frett, B.; McConnell, N.; Smith, C. C.; Wang, Y.; Shah, N. P.; Li, H.-y. Eur. J. Med. Chem. 2015, 94, 123-131. doi:10.1016/j.ejmech.2015.02.052

20. Baviskar, A. T.; Madaan, C.; Preet, R.; Mohapatra, P.; Jain, V.; Agarwal, A.; Guchhait, S. K.; Kundu, C. N.; Banerjee, U. C.; Bharatam, P. V. J. Med. Chem. 2011, 54, 5013-5030. doi:10.1021/jm200235u

21. Bode, M. L.; Gravestock, D.; Moleele, S. S.; van der Westhuyzen, C. W.; Pelly, S. C.; Steenkamp, P. A.; Hoppe, H. C.; Khan, T.; Nkabinde, L. A. Bioorg. Med. Chem. 2011, 19, 4227-4237. doi:10.1016/j.bmc.2011.05.062

22. Enguehard-Gueiffier, C.; Gueiffier, A. Mini-Rev. Med. Chem. 2007, 7, 888-899. doi:10.2174/138955707781662645

23. Zhou, H.; Wang, W.; Khorev, O.; Zhang, Y.; Miao, Z.; Meng, T.; Shen, J. Eur. J. Org. Chem. 2012, 5585-5594. doi:10.1002/ejoc.201200542

24. Ugi, I.; Meyr, R.; Fetzer, U.; Steinbrückner, C. Angew. Chem. 1959, 71, 386. doi:10.1002/ange.19590711110

25. Ugi, I.; Steinbrückner, C. Angew. Chem. 1960, 72, 267-268. doi:10.1002/ange.19600720709

26. Blackburn, C.; Cuan, B.; Fleming, P.; Shiosaki, K.; Tsai, S. Tetrahedron Lett. 1998, 39, 3635-3638. doi:10.1016/S0040-4039(98)00653-4

27. Groebke, K.; Weber, L.; Mehlin, F. Synlett 1998, 661-663. doi:10.1055/s-1998-1721

28. Bienaymé, H.; Bouzid, K. Angew. Chem., Int. Ed. 1998, 37, 2234-2237. doi:10.1002/(SICI)1521-3773(19980904)37:16<2234::AID-ANIE2234>3 .0.CO;2-R

29. Hulme, C.; Bienaymé, H.; Nixey, T.; Chenera, B.; Jones, W.; Tempest, P.; Smith, A. L. Methods Enzymol. 2003, 369, 469-496. doi:10.1016/S0076-6879(03)69024-5

30. Kruithof, A.; Ruijter, E.; Orru, R. V. A. Chem. - Asian J. 2015, 10 , 508-520. doi:10.1002/asia.201403207

31. Devi, N.; Rawal, R. K.; Singh, V. Tetrahedron 2015, 71, 183-232. doi:10.1016/j.tet.2014.10.032

32. Shaaban, B.; Abdel-Wahab, B. F. Mol. Diversity 2016, 20, 233-254. doi:10.1007/s11030-015-9602-6

33. Hulme, C.; Lee, Y.-S. Mol. Diversity 2008, 12, 1-15. doi:10.1007/s11030-008-9072-1

34. Che, C.; Xiang, J.; Wang, G.-X.; Fathi, R.; Quan, J.-M.; Yang, Z. J. Comb. Chem. 2007, 9, 982-989. doi:10.1021/cc070058a

35. Xiang, J.; Yang, H.; Che, C.; Zou, H.; Yang, H.; Wei, Y.; Quan, J.; Zhang, H.; Yang, Z.; Lin, S. PLoS One 2009, 4, e4361. doi:10.1371/journal.pone.0004361

36. Lin, S.; Che, C.; Li, S.; Yang, B.; Xin, S. C. Preparation of Tetracyclic Fused Imidazo[1,2-a] Pyridine Compounds for Treating Gastric Cancer. Chinese Patent CN105017253 A, Nov 14, 2015.

37. Kysil, V.; Khvat, A.; Tsirulnikov, S.; Tkachenko, S.; Williams, C.; Churakova, M.; Ivachtchenko, A. Eur. J. Org. Chem. 2010, 1525-1543. doi:10.1002/ejoc.200901360

38. Kaichala, T.; Yetra, S. R.; Roy, T.; Biju, A. T. Green Chem. 2013, 15, 1608-1614. doi:10.1039/c3gc40454d

39. Fokas, D.; Ryan, W. J.; Cascbier, D. S.; Coffen, D. L. Tetrahedron Lett. 1998, 39, 2235-2238. doi:10.1016/S0040-4039(98)00234-2 


\section{License and Terms}

This is an Open Access article under the terms of the Creative Commons Attribution License

(http://creativecommons.org/licenses/by/2.0), which permits unrestricted use, distribution, and reproduction in any medium, provided the original work is properly cited.

The license is subject to the Beilstein Journal of Organic Chemistry terms and conditions:

(http://www.beilstein-journals.org/bjoc)

The definitive version of this article is the electronic one which can be found at:

doi:10.3762/bjoc. 12.145 